\title{
Terorisme sebagai Cabaran Ideologi Muslim Masa Kini: Satu Analisis dari Perspektif Falsafah
}

\author{
Terrorism as Ideological Challenge on Contemporary Muslim: A Philosophical Analysis
}

\author{
ZUL`AZMI YAAKOB* \& AHMAD SUNAWARI LONG1
}

\begin{abstract}
Terrorism is currently becoming an ideological challenge for Muslims in contemporary world. The rise of terrorist groups such as the Islamic State (IS) and others who claimed themselves as jihadist and propagates Islamic jihad similar to the idea of the medieval 'Holy War' not only target non-Muslims or kuffar, but also their Muslim brothers respectively. This act of terrorism raised dilemma among Muslim societies in general whether to support the extreme groups or to defy them as they portrayed themselves as representing the whole Muslims whereas in fact they only represent a group of disillusioned Muslims. This paper aims at analysing their ideological challenge from the philosophical point of view and Islamic ethics. Generally, this analysis emphasizes on the importance of Islamic ethics and law in order to achieve true understanding of jihad.
\end{abstract}

Keywords: akhlaq, Islamism, jihad, philosophy, Muslim ethics, terrorism

Kebelakangan ini terlalu banyak ideologi yang ciri-cirinya berbentuk fahaman keras dan radikal ataupun ekstrem, bahkan berpotensi mempengaruhi masyarakat sekeliling kepada tindakantindakan yang melampaui batas. Ia termasuklah berbentuk provokasi, ugutan, keganasan, penculikan, penderaan, rampasan, peperangan, pengeboman, pembunuhan dan sebagainya. Terdapat sebilangan masyarakat dunia luar terutamanya Barat begitu fokus melabelkan kelompok Muslim sebagai pengganas, dengan gelaran terrorist (teroris) mahupun extremist (ekstremis atau radikalis). Ia disebabkan oleh pendedahan pelbagai pihak media Barat berhubung kejadian keganasan di seluruh dunia yang kerap menuding jari kepada golongan Muslim sebagai pelakunya. Golongan teroris ini juga seringkali disentimenkan oleh media Barat sebagai golongan pelampau agama. Label-label sedemikian masih boleh diabaikan oleh umat Islam secara dasarnya selagi mana sikap media Barat begitu berat sebelah dalam memainkan isu terorisme. Malah kegagalan Barat memberikan justifikasi tepat tentang terorisme yang dihubungkan dengan istilah 'jihad' merupakan satu bentuk manipulasi persepsi.

Istilah 'terorisme' disinonimkan maksudnya dengan penggunaan kekerasan dalam memastikan segala matlamat yang dikehendaki tercapai. Ia termasuklah melalui aktiviti penculikan, rampasan, pembunuhan dan peperangan. Semuanya dikategorikan sebagai ganas dan melampaui batas (Kamal 2008). Pada hari ini, masyarakat Islam seluruh dunia semakin

\footnotetext{
${ }^{1}$ Zul`azmi Yaakob*(Corresponding author), Ph.D, Lecturer, Dept. of Theology and Philosophy, Faculty of Islamic Studies, Universiti Kebangsaan Malaysia, 43600 BANGI, Selangor, Malaysia, email: zulazmi@ukm.edu.my; Ahmad Sunawari Long, Assoc. Professor, Dept. of Theology and Philosophy, Faculty of Islamic Studies, Universiti Kebangsaan Malaysia, 43600 BANGI, Selangor, Malaysia, email: aslong@ukm.edu.my.
} 
keliru dalam memahami ideologi bawaan golongan radikal tersebut terutama sekali daripada gerakan atau kumpulan militan Islam sepertimana IS (Islamic State) dan sebagainya. Merumitkan keadaan, didapati semakin banyak pengakuan secara terbuka oleh mereka ini sebagai pelaku yang mendakwa bahawa diri masing-masing adalah 'pejuang' Islam iaitu mujahid ataupun mujahidin. Pusat membeli-belah, hotel dan tempat laluan ramai telah dijadikan lokasi pembunuhan dan pengeboman berani mati oleh kelompok tersebut. Mereka ini mendakwa apa yang dilakukannya bukanlah satu usaha berbentuk 'keganasan', sebaliknya mentafsirkan perbuatan tersebut sebagai 'jihad' walaupun pembunuhan dan pengeboman tersebut telah meragut nyawa orang ramai termasuklah golongan warga emas dan kanakkanak. Di samping itu, mereka mendakwa tindakan tersebut adalah sebagai satu respons kepada dunia Barat tentang erti sebenar 'keadilan' yang selama ini sering dimanipulasi dan didiskriminasikan oleh Barat ke atas masyarakat minoriti Muslim mahupun ke atas kebanyakan negara Islam. Sebab itulah segala bentuk pemberontakan dan peperangan oleh kelompok militan Muslim sedemikian sentiasa mendapat sokongan oleh segelintir masyarakat Islam seluruh dunia walaupun keganasan yang dilakukan amatlah melampau sehingga menghilangkan nilai kemanusiaan dan akhlak Islamiah. 'Keganasan' tersebut masih dianggap sebagai 'jihad' oleh kumpulan militan Islam yang bertanggungjawab, juga penyokongnya termasuklah masyarakat luar. Ia dikatakan mendapat sokongan oleh beberapa pihak tertentu dalam kalangan Muslim sendiri kerana turut bersimpati dengan nasib umat Islam terutamanya di negara-negara bergolak dan mengalami penindasan oleh negara-negara kuasa besar.

Namun begitu, semenjak akhir-akhir ini didapati kejadian keganasan yang dilakukan oleh golongan pelampau, radikal ataupun ekstrem ini bukan sahaja memfokuskan mangsanya adalah non-Muslim, malah turut melakukannya ke atas masyarakat Islam sendiri. Dengan kata lain, masyarakat Islam itu sendiri diperlakukan secara keganasan oleh golongan seagama mereka. Pelampau ataupun pengganas ini beranggapan masyarakat Islam yang diperlakukan tersebut adalah golongan yang 'halal' darahnya untuk didera atau dibunuh, malah didakwa sebagai 'tali barut' Barat, 'kafir' (walaupun mereka adalah Muslim) menurut kebekuan 'ijtihad' mereka. Semua ini telah memberikan satu persepsi yang mengelirukan sama ada kepada pihak Barat mahupun Islam. Masyarakat Islam menjadi semakin dalam dilemma sama ada mahu menyokong ataupun menolak individu dan kumpulan militan Islam. Menolaknya mungkin dilihat sebagai usaha berbentuk simpati kerana penindasan yang dialami selama ini. Akan tetapi, menyokongnya pula akan memberikan imej yang tidak baik tentang Islam dan ajarannya kerana keganasan yang dilakukan oleh mereka ini sebenarnya terlalu melampaui batas. Ia termasuklah penyembelihan, pembunuhan dan pengeboman di dalam masjid, pasar dan tempat awam. Ini mengorbankan ramai Muslim yang sedang beribadat dan mencari rezeki. Lebih menyedihkan, mangsa yang terlibat adalah golongan warga emas dan kanak-kanak.

\section{Terorisme Meminggirkan Hikmah dan Akhlak Islamiah}

Dengan kemunculan pelbagai kelompok militan bercirikan fahaman radikal seperti IS ataupun ISIS, bahkan semakin terbuka dan lantang membuat pengakuan (menerusi media) tentang aktiviti-aktiviti keganasan yang telah dilakukan dan bakal dilakukan, nampaknya perkara ini perlu dilihat sebagai satu cabaran dalam ideologi Muslim masa kini. Isu ini perlu dilihat semula dan dianalisis dari perspektif falsafah agar masyarakat dapat memahami tentang ajaran Islam yang sebenar, malah menolak unsur keganasan sebagaimana yang diperjuangkan oleh teroris.

Istilah 'teroris' yang dimaksudkan sebagai 'pengganas' mempunyai banyak persamaan ertinya dengan istilah 'ekstremis'. Dalam Kamus Dewan (Noresah Baharom 2007), istilah 'ekstrem' dimaksudkan sebagai 'melampau' atau 'keterlaluan' manakala 'ekstremis' pula diertikan sebagai 'pelampau' ataupun 'golongan yang sikapnya (termasuklah pendiriannya) 
dalam sesuatu hal (seperti politik) adalah melampaui batas kesederhanaan'. Begitu juga istilah 'ekstremisme' yang merujuk sebagai 'fahaman, sikap atau perlakuan yang melampaui batas'. Istilah 'melampaui' di sini membawa maksud 'melebihi had dan ketentuan yang sewajarnya', 'melanggari tatatertib' ataupun 'berlebih-lebihan'.

Biarpun setiap manusia ada hak masing-masing dalam membuat tindakan, namun dari sudut falsafahnya ia tetap tidak boleh melampaui batasan kemanusiaan apatah lagi menghilangkan nilai akhlaknya. Segala tindakan manusia mestilah bertujuan mendekatkan diri kepada Allah (s.w.t.) (Ibn Manzur 1996). Dalam konteks dunia Islam, fahaman terorisme mempunyai hubungkait dengan fahaman radikalisme ataupun ektremisme. Paling bermasalah, apabila golongan tersebut turut mensasarkan kelompok Muslim lain dengan cara kekerasan, pembunuhan dan pengeboman. Peristiwa tersebut begitu banyak berlaku di negara-negara Islam seperti di Asia Barat dan Asia Tenggara. Mereka merasakan cara keganasan tersebut adalah satu 'jihad'. Situasi tersebut turut menarik pelbagai kelompok Muslim lain termasuklah di Malaysia untuk menubuhkan kumpulan 'jihad' masing-masing seperti Jemaah Islam, Kumpulan Militan Malaysia, Al-Ma'unah dan sebagainya. Mereka turut dikatakan terlibat dengan peperangan dan pengeboman di Selatan Filipina dan Bali, Indonesia (Jabatan Kemajuan Islam Malaysia t.th.).

Dari sudut falsafah akhlak, pelampau ataupun teroris dianggap sebagai golongan yang tidak berhikmah iaitu tiada sifat kebijaksanaan. Mereka ini sebaliknya berfikiran sempit, terburu-buru dan mengikut hawa nafsu dalam menghukum orang lain termasuklah sesama umat Islam sendiri, seterusnya melaksanakannya secara kekerasan dan keganasan demi memastikan matlamat mereka tercapai. Ahli Falsafah Islam seperti al-Farabi (m. 950M) dan Ibn Rushd (m. 1198M) sentiasa menggalakkan budaya berhikmah kerana akal yang Allah (s.w.t.) anugerahkan adalah untuk memastikan manusia berusaha menjadi insan yang bijaksana dan cintakan keamanan, bukannya untuk membentuk manusia yang radikal serta ganas. Ia merupakan satu usaha untuk memperjuangkan budaya berfikir dan mengambil iktibar ke atas segala ciptaan dan kewujudan alam, sebagai usaha murni umat manusia untuk mendekati Penciptanya (Ibn Rushd 1986; al-Farabi 1995).

Terorisme yang bersifat keganasan, radikal dan melampau batas secara pemahaman ideologi mahupun perbuatan, sebenarnya telah meminggirkan kepentingan nilai akhlak. Ahli falsafah Islam seperti Ibn Miskawayh (m. 1030M) menekankan bahawa pembersihan jiwa manusia perlulah diberikan keutamaan dalam melahirkan akhlak yang berkualiti, seterusnya melaksanakan 'jihad' secara adil, cermat dan ikhlas (Ibn Miskawayh 1961). Namun, ia bukanlah 'jihad' yang memfokuskan kepada peperangan mengangkat senjata, sebaliknya adalah peperangan melawan hawa nafsu. Situasi ini turut ditekankan oleh Imam al-Ghazali (m. $1111 \mathrm{M}$ ). Menurut beliau, budaya keganasan bukanlah sesuatu perbuatan yang adil, sebaliknya perbuatan yang melampaui batas serta ketidakadilan (al-Ghazali 1964). Keganasan dan kekejaman bukanlah dianggap satu 'jihad', sebaliknya sesuatu yang tidak berakhlak, tidak beretika dan tidak bermoral apatah lagi jika dilihat dari sudut falsafah Islam.

Umat Islam sepatutnya meneladani Rasulullah (s.a.w.) yang ternyata 'jihad' Baginda sepanjang perutusannya adalah menentang kejahilan, kemiskinan, hawa nafsu, sifat bongkak, munafik dan sebagainya. Dalam usaha Baginda (s.a.w.) memenuhi amalan hidupnya, begitu banyak perkara yang ditekankan sebagai 'jihad'. Namun kebanyakannya berkisar pada aspek akidah dan akhlak, bukannya peperangan, apatah lagi keganasan. Tetapi agenda peperangan jugalah yang sentiasa disentimenkan oleh golongan yang mendakwa mereka adalah 'mujahid' ataupun 'mujahidin' pada masa kini, sambil mentafsirkan tindakan tersebut adalah sepertimana yang dituntut oleh Nabi Muhammad (s.a.w.), agar 'matlamat menghalalkan cara' atas nama 'jihad' tersebut dapat dilaksanakan tanpa sebarang persoalan termasuklah dari segi Maqasid alShari ah (Jabatan Kemajuan Islam Malaysia t.th.). 'Jihad' besar pertama Rasullah (s.a.w.) adalah 
mencari ilmu sebagaimana penerimaan wahyu pertama iaitu surah al-Alaq (96:1-5). Jika merujuk kepada pendapat ahli falsafah seperti al-Farabi (m. 950M), beliau turut berpendapat bahawa pembentukan sebuah negara yang baik adalah apabila masyarakatnya sentiasa menjaga akhlaknya. Apabila akhlak telah dibentuk dengan baik, bermakna suasana aman sentiasa dapat diberikan keutamaan berbanding keganasan dan pembunuhan (al-Farabi 1991). Malah, keutamaan dan ketaatan (mengikut undang-undang) kepada pemerintah sentiasa dipertahankan demi memastikan proses perubahan masyarakat sentiasa berlaku dalam keadaan aman dan harmoni.

\section{Terorisme Meminggirkan Undang-undang}

Istilah 'ekstremisme' mempunyai persamaan makna hubungan dengan istilah 'radikalisme' yang diertikan sebagai 'fahaman (termasuklah aliran dan kepercayaan) yang menginginkan perubahan yang mendadak dalam arena politik dan sosial' (Noresah Baharom 2007). Justeru daripada sikap yang terlalu inginkan perubahan secara mendadak, maka situasi tersebut seringkali menyebabkan kelompok manusia yang 'radikal' ataupun berfahaman 'radikalisme' begitu cenderung untuk berpendirian ataupun melaksanakan sesuatu misi dan usahanya secara membelakangkan undang-undang terutama sekali undang-undang yang telah diiktiraf dalam sesebuah negara. Golongan tersebut juga dikatakan lebih mengutamakan 'matlamat' berbanding 'cara' walaupun bersifat falsafah Machiavellianisme yang secara fahaman politiknya merujuk kepada golongan yang suka mengambil kesempatan (oportunis), bersifat licik dan pandai menipu. Ini kerana, slogan yang diperjuangkannya adalah 'matlamat menghalalkan cara'.

Falsafah Machiavellianisme dikaitkan dengan tokoh falsafah Barat dari Itali bernama Niccolo Machiavelli (m. 1527M). Ia memaparkan bagaimana terdesaknya beliau menyuburkan fahaman dan falsafah yang 'menghalalkan' cara apa sekalipun asalkan matlamat yang diinginkan oleh seseorang itu terlaksana terutamanya melibatkan soal politik, pangkat, harta dan kekuasaan. Dalam keadaan yang memberikan peluang kekuasaan yang lebih besar kepada si pelaku, maka seseorang atau sesebuah masyarakat 'dibenarkan' untuk melanggari undangundang ataupun institusi kehakiman, membelakangkan arahan pemerintah, memanipulasi pemikiran rakyat, mencetuskan keganasan, kezaliman, pembunuhan dan peperangan asalkan peluang memperolehi kekuasaan tersebut tercapai. Malah, seseorang atau sesebuah masyarakat turut digalakkan mengampu pemerintah pada tahap semaksimum mungkin selagi ia bakal memberikan pulangan seperti pangkat, kekuasaan, harta dan kedudukan tinggi kepada si pelaku (Machiavelli 1935). Dalam situasi sedemikian, 'matlamat' menjadi keutamaan sehingga boleh menghalalkan 'caranya'.

Hal ini berbeza dengan pandangan ahli falsafah era klasik seperti Socrates (m. 399SM). Bagi Socrates, walau apa sekalipun niat seseorang itu untuk memperbetulkan keadaan, tetapi selagi mana ia menggunakan cara yang membelakangkan undang-undang negara, maka selagi itulah ia dianggap sebagai perbuatan yang tidak bermaruah dan tidak beretika. Itulah sebab mengapa Socrates menolak untuk lari daripada penjara walaupun diberi peluang oleh pelbagai pihak berpengaruh bagi memastikan beliau terlepas daripada penjara dan hukuman mati. Sebagaimana yang dicatatkan oleh Plato, didapati Socrates begitu mempertahankan institusi perundangan. Pada pandangan beliau, mentaati undang-undang adalah gambaran sebenar etika hidup seseorang. Beliau sanggup menerima hukuman mati daripada membenarkan berlakunya budaya menyogok (rasuah) oleh pihak berpengaruh ke atas pihak penjara yang sedaya upaya untuk menolongnya serta membawa Socrates keluar daripada Athens. Cara sedemikian dianggap membelakangkan undang-undang kerana budaya rasuah oleh pihak luar dan budaya tidak amanah oleh pegawai penjara. Socrates tidak kisah walaupun dihukum mati di atas kesalahan yang bukan beliau lakukan, tetapi ia dianggap lebih baik dan bermaruah dari segi 
etikanya kerana sentiasa mentaati undang-undang. Selagi mana matlamat adalah betul tetapi melalui cara yang salah, maka ia dianggap oleh Socrates sebagai satu kesalahan yang besar, perbuatan buruk, malah berdosa (Plato 1954; Woodruff 2014).

Kepentingan mentaati undang-undang sebagai cerminan amalan baik dan kemuliaan etika hidup seseorang turut dipersetujui oleh Aristotle (m. 322SM). Beliau sendiri beranggapan bahawa mentaati undang-undang adalah satu perbuatan keadilan manakala membelakangkan undang-undang adalah satu ketidakadilan (Aristotle 1934). Dari sudut falsafah Islam, Ibn Miskawayh (m. 1030M) juga menekankan betapa pentingnya keadilan iaitu segala perbuatan yang selari dengan undang-undang (Ibn Miskawayh 1961). Justeru, 'matlamat' adalah tidak boleh menghalalkan 'cara'. Di situlah pentingnya sifat kesabaran dan ketaatan dalam menggunakan prosedur yang betul serta diiktiraf oleh negara.

\section{Menangani Fahaman Terorisme atas Nama 'Jihad' dalam kalangan Muslim Malaysia}

Dalam konteks Malaysia, isu 'jihad' turut mendapat perhatian kerana kebelakangan ini terutamanya melalui media sosial semakin banyak ideologi terorisme disebarkan walaupun di atas nama 'jihad'. Perkara pertama yang harus diberikan perhatian dalam memastikan budaya keganasan tidak berkembang walaupun atas nama 'jihad' ataupun 'mempertahankan agama Islam', adalah dengan memperbetulkan penyimpangan makna ataupun penyelewengan tafsiran golongan pelampau (pengganas atau teroris) tersebut terhadap kandungan makna ayat-ayat alQuran dan Hadis. Paling utama, pengertian 'jihad' itu sendiri perlu diperbetulkan maksudnya. Bagi kebanyakan kelompok militan Islam, 'jihad' ditafsirkan hanya semata-mata merujuk kepada 'peperangan mengangkat senjata'. Inilah yang menyebabkan mengapa golongan tersebut sering melakukan pembunuhan, rampasan, pengeboman dan sebagainya. Mengikut tafsiran mereka, keganasan dan pembunuhan yang dilakukan adalah bertepatan dengan makna sebenar 'jihad' yang dimaksudkan oleh al-Quran dan Hadis. Sedangkan mereka keliru dalam memahaminya secara sempit kerana 'jihad' tidak semestinya ditakrifkan sebagai 'mengangkat senjata'. Malah, kesungguhan untuk mengekalkan keamanan dan mencegah daripada sebarang bencana seperti kebuluran dan peperangan, juga merupakan salah satu 'jihad' yang amat besar. Hakikatnya, 'jihad' merupakan penggemblengan tenaga dengan menggunakan cara-cara yang aman (Jabatan Kemajuan Islam Malaysia t.th.). Pemahaman terhadap maknanya perlulah mengikut acuan pemikiran Islam yang mengambil kira semua aspek termasuklah dari sudut sebab dan kemaslahatan sebagaimana dalam Maqasid al-Shari'ah yang menekankan pemeliharaan terhadap agama, nyawa, akal, keturunan dan harta. Apa yang dapat dijelaskan, Islam begitu mengutamakan pendekatan secara harmoni termasuklah menggunakan saluran yang betul iaitu berlandaskan undang-undang.

Kedua, institusi pendidikan sama ada di peringkat sekolah rendah, menengah, madrasah, malah pusat pengajian tinggi dalam negara mahupun yang belajar di luar negara perlulah dipantau oleh pihak berkuasa. Pemantauan dan pengawasan bukan sahaja difokuskan kepada pelajar, malah paling penting adalah tenaga pengajar kerana dari individu-individu sedemikianlah ideologi terorisme, ekstremisme dan radikalisme mudah tersebar apatah lagi mereka yang pernah mempunyai pengalaman belajar ataupun menerima latihan di negara yang bergolak dengan peperangan. Ketiga, ruangan media massa terutamanya media sosial perlulah dikawal oleh pihak pemerintah dan institusi keluarga sebagai langkah awal dalam membendung pengaruh ideologi terorisme. Ini disebabkan kebelakangan ini didapati kebanyakan golongan yang terjebak dengan ideologi terorisme mahupun aktiviti-aktiviti keganasan yang dianjurkan adalah berhubung melalui media sosial. Dalam situasi sedemikian, hak kebebasan media mahupun hak kebebasan mana-mana pertubuhan dan individu tidak boleh dilonggarkan seluasluasnya. Akhir sekali, pendidikan akhlak perlu diperkasakan kembali di peringkat institusi 
kekeluargaan dan institusi pendidikan, malah perlu ditekankan secara konsistem dalam manamana majlis ilmu, budaya kerja dan pergaulan. Jika perkara ini sentiasa diambil perhatian, sudah tentunya budaya 'mengkafirkan' sesama umat Islam tidak berlaku, falsafah politik Machiavellianisme dapat ditangani, malah adab sopan serta santun (termasuklah berakal budi) sentiasa dijunjung tinggi seterusnya melahirkan masyarakat yang harmoni, wasatiyah dan penuh perpaduan walaupun dalam konteks menyebarkan agama Islam.

Secara rumusan, 'keganasan' ataupun 'terorisme' tidak boleh disamakan maksudnya sebagai 'jihad'. 'Jihad' adalah perjuangan suci dari sudut matlamat dan caranya kerana ia tetap terikat dengan akhlak Islamiah, bahkan tidak semestinya bermaksud peperangan 'mengangkat senjata'. Sebab itulah falsafah bagi 'keganasan' atau 'terorisme' adalah falsafah Machiavellianisme manakala falsafah bagi 'jihad' adalah falsafah akhlak yang nilainya adalah berpaksikan Tuhan, malah penuh adab, hikmah, sopan santun dan kemanusiaan. Terorisme dianggap sebagai lawan kepada undang-undang kerana kebanyakan ahli falsafah klasik mahupun Islam tetap berpendirian bahawa ketaatan kepada undang-undang adalah lambang keharmonian dalam menegakkan keadilan.

\section{References}

Aristotle. 1934. Nicomachean Ethics. Terj. H. Rackham. London: William Heinemann Ltd. al-Farabi, Abu Nasr. 1991. Kitab Ara' ahl al-madinah al-fadilah. Beirut: Dar al-Mashriq. 1995. Kitab Tahsil al-sa adah. Beirut : Dar wa Maktabat al-Hilal.

Al-Ghazali. 1964. Mizan al-'amal. Sunt. Sulayman Dunya. Cairo: Dar al-Ma`arif.

Ibn Manzur. 1996. Lisan al-'Arab. Jil. 3. Beirut : Dar Ihya' al-Turath al-`Araby.

Ibn Miskawayh, Ahmad. 1961. Tahdhib al-akhlaq. Beirut: Dar Maktabat al-Hayah.

Ibn Rushd. 1986. Kitab Fasl al-maqal wa taqrir ma bayn al-shari ah wa al-hikmah min al-ittisal. Sunt. Albayr Nasri Nadir. Beirut: Dar al-Mashriq.

JAKIM. t.th. Jihad dalam konteks kontemporari di Asia Tenggara. Kertas kerja Mesyuarat Pegawai-pegawai Kanan (SOM) kali ke-28.

Kamal, Muhammad. 2008. The meaning of terrorism: a philosophical inquiry. National Centre of Excellence for Islamic Studies. NCEIS Research Paper.

Machiavelli, Niccolo. 1935. The Prince. Terj. Luigi Ricci. London: Oxford University Press.

Noresah Baharom. 2007. Kamus Dewan. Ed. ke-4. Kuala Lumpur : Dewan Bahasa dan Pustaka.

Plato. 1954. The Last Days of Socrates: The Apology, Crito, Phaedo. Transl. Hugh Tredennick. Harmondsworth: Penguin Books.

Woodruff, P. 2014. Plato's shorter ethical works. Stanford Encyclopedia of Philosophy. (atas talian) http://plato.stanford.edu/entries/plato-ethics-shorter/\#11. Diakses pada 10 January 2015. 